\title{
The COMPANIES' CREDITORS ARRANGEMENT ACT AND THE PETROLEUM INDUSTRY: The Blue Range Resource Corporation Proceedings
}

\author{
DOUGLAS S. NISHIMURA
}

This article provides an analysis of $s .11$ of the Companies' Creditors Arrangement Act and the decisions arising out of the Blue Range litigation. While comparing the CCAA legislation with the Bankruptcy and Insolvency Act and the United States Bankruptcy Code the author analyzes the impact of the Blue Range Decisions on insolvency law and the petroleum indusiry.
Cet article fait l'analyse de l'article II de la Loi sur les arrangements avec les créanciers des compagnies et des décisions qui découlent de l'affaire Blue Range. Tout en comparant la Loi sur les arrangements avec les créanciers des compagnies à la Loi sur la faillite et l'insolvabilité et au Bankrupcy Code aux États-Unis, l'auteur fait l'analyse de l'incidence des décisions de l'affaire Blue Range sur la loi sur l'insolvabilité et l'industrie pétrolière.

\section{TABLE OF CONTENTS}

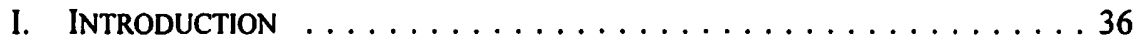

II. OVERVIEW OF THE COMPANIES' CREDITORS

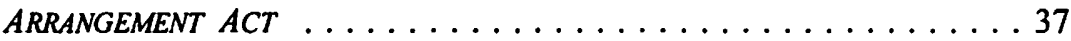

A. General PURPOSE AND SCHEME Of THE $A C T \ldots \ldots \ldots \ldots 37$

B. APPLICABILITY OF THE CCAA $\ldots \ldots \ldots \ldots \ldots \ldots \ldots$

C. THE ROLE OF THE MONITOR $\ldots \ldots \ldots \ldots \ldots \ldots \ldots \ldots$

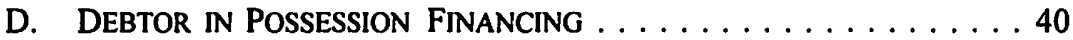

E. ENVIRONMENTAL CONCERNS $\ldots \ldots \ldots \ldots \ldots \ldots \ldots 40$

F. Contents of the Plan $\ldots \ldots \ldots \ldots \ldots \ldots \ldots \ldots 40$

G. Procedural Steps $\ldots \ldots \ldots \ldots \ldots \ldots \ldots \ldots 41$

III. BACKGROUND OF BLUE RANGE RESOURCE CORPORATION . . . . . 42

IV. THE SET-OFF, TERMINATION OF CONTRACTS, AND

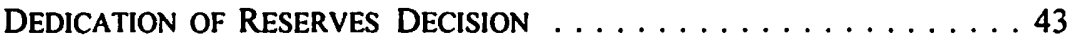

A. Legal AND EQUITABLE SET-OFF $\ldots \ldots \ldots \ldots \ldots \ldots \ldots 44$

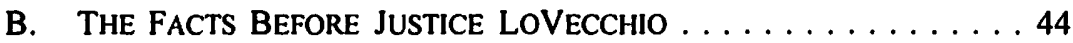

C. THE Set-Off AMENDMENT $\ldots \ldots \ldots \ldots \ldots \ldots \ldots \ldots 45$

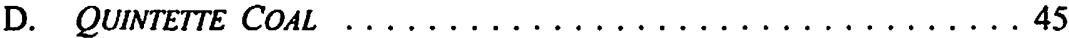

E. THE DeCiSION OF JUSTICE LoVECCHIO $\ldots \ldots \ldots \ldots \ldots \ldots 46$

F. THE DECISION OF THE COURT OF APPEAL $\ldots \ldots \ldots \ldots \ldots 47$

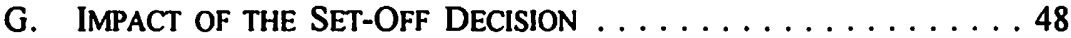

H. THE TeRmination OF CONTRACTS ISSUE $\ldots \ldots \ldots \ldots \ldots \ldots 50$

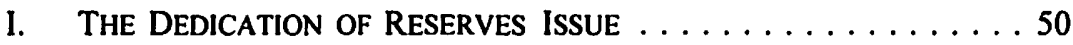

Douglas S. Nishimura is an associate with the firm of Burnet, Duckworth \& Palmer, practicing in the areas of insolvency and commercial litigation. Portions of this article have been extracted from a previous article by Mr. Nishimura and Brian P. O'Leary of Bumet, Duckworth \& Palmer, "Eligible Financial Contracts and Setoffs under the Companies' Creditors Arrangement Act" 12 Comm. Insol. R., as well as an overview of the Companies' Creditors Arrangement Act by Brian P. O'Leary and Alison Z.A. Campbell of Burnet, Duckworth \& Palmer, published in the Spring 1999 issue of On Record, the in-house publication of Burnet, Duckworth \& Palmer. 
V. Eligible Financial Contracts $\ldots \ldots \ldots \ldots \ldots \ldots \ldots \ldots . \ldots \ldots$

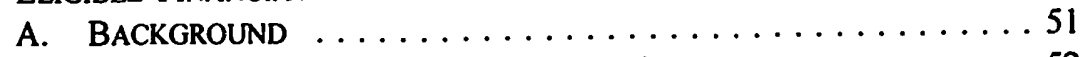

B. The Eligible Financial Contract Amendment ....... 52

C. HISTORY OF THE Eligible FINANCIAL

Contract AMENDMENT $\ldots \ldots \ldots \ldots \ldots \ldots \ldots \ldots$

D. THE CONSEQUENCES OF A FINDING IN

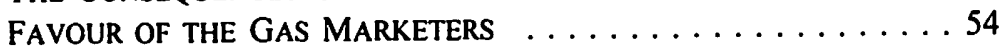

E. Primary ARguments for the Gas Marketers . . . . . . . 54

F. THE ARguments Against the Gas Marketers ........ 55

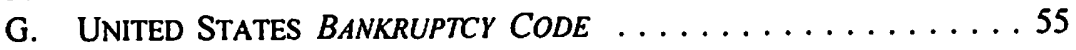

H. THE DECISION OF JUSTICE LOVECCHIO

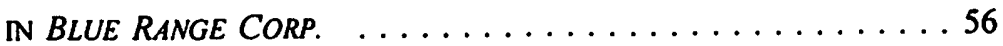

I. THE DECISION OF THE COURT OF APPEAL

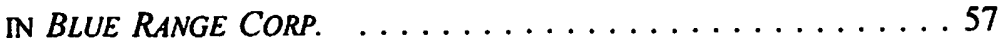

J. IMPACT OF THE ELIGIBLE FINANCIAL

CONTRACT DECISION ................. 58

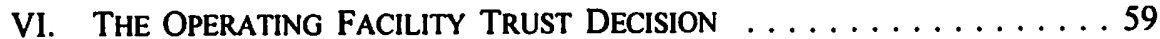

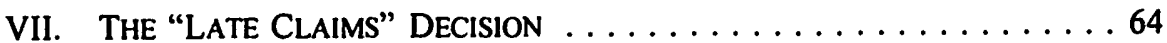

VIII. BUILDERS' LIENS - PREVENIENT ARRANGEMENTS $\ldots \ldots \ldots \ldots 66$

IX. The Subordinated Damages Decision $\ldots \ldots \ldots \ldots \ldots \ldots \ldots 8$

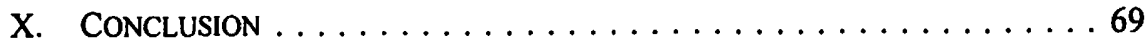

\section{INTRODUCTION}

The Companies' Creditors Arrangement Act' is federal legislation created during the 1930s. Since the 1980s, the CCAA has become the tool of choice for companies undergoing financial restructuring. Recently the CCAA has been used in Alberta in the restructurings (or attempted restructurings) of many types of businesses, including both a coal mining company and a major national airline. The petroleum industry has also used the CCAA, both successfully and unsuccessfully, as evidenced by the insolvencies of Oakwood Petroleums Ltd., Hurricane Hydrocarbons Ltd., Fracmaster Ltd., and Merit Energy Ltd.

The recent $C C A A$ proceedings involving Blue Range Resource Corporation ${ }^{2}$ have led to a number of decisions of great importance to companies in the "oil patch" as well as to the financial community and the insolvency bar. A number of reported decisions of the Court of Queen's Bench of Alberta and the Court of Appeal of Alberta have been issued in the Blue Range proceedings, all dealing with important and novel issues. Further, leave has been sought to appeal one decision to the Supreme Court of Canada.

R.S.C. 1985, c. C-36 [hereinafter CCAA].

$2 \quad$ Re Blue Range Resource Corporation (1999), 245 A.R. 154 (Q.B.); Re Blue Range Resource Corporation, [1999] A.J. No. 929, online: QL (AJ); Re Blue Range Resource Corporation (1999), 251 A.R. I (Q.B.); Re Blue Range Resource Corporation (1999) 49 C.L.R. (2d) 133 (Alta. Q.B.); Re Blue Range Resource Corporation (1999), 245 A.R. 172, [1999] 12 W.W.R. 616; Re Blue Range Resource Corporation, [2000] A.J. No. 1032 (C.A.); Re Blue Range Resource Corporation, [2000] A.J. No. 1232 (C.A.); Re Blue Range Resource Corporation, [2000] A.J. No. 830 (C.A.) [hereinafter Blue Range]. 
The purpose of this article is to review the Blue Range decisions and to comment on their impact on the petroleum industry and on insolvency law in general. Two of the decisions, dealing with set-off and eligible financial contracts, are dealt with at greater length than are the others due to their importance to, and the attention they have already received by, the petroleum industry.

\section{OVERVIEW OF THE COMPANIES' CREDITORS ARRANGEMENT ACT}

\section{A. General Purpose and Scheme of THe ACT}

According to its accompanying jurisprudence, the $C C A A$ 's purposes include the following:

(1) to permit an insolvent company to avoid, or be discharged from, bankruptcy by making a compromise or arrangement with its creditors;

(2) to permit a company to remain in business notwithstanding that it is insolvent;

(3) to protect an insolvent company from proceedings by creditors that would prevent the company from carrying out the terms of a compromise or arrangement;

(4) to protect the interests of creditors and to permit an orderly distribution of the debtor company's affairs;

(5) to maintain the status quo for a period while the insolvent company attempts to gain the approval of its creditors for an arrangement which will enable the company to remain in operation for the future benefit of the company and its creditors;

(6) to permit equal treatment of creditors of the same class; and

(7) to preserve the insolvent company as a viable operation and to reorganize its affairs to the benefit not only of the debtor but of the creditors. ${ }^{3}$

To achieve these results, the $C C A A$ provides a court with the power to stay all proceedings against the debtor company while the company develops a plan of arrangement and presents it to its creditors.

The $C C A A$ is the closest Canadian statutory framework to chapter 11 "debtor in possession" proceedings under the United States Bankruptcy Code. ${ }^{4}$ Under the CCAA, the debtor company remains in possession of its assets and can apply to the court for an order staying all proceedings against it pending a meeting of its creditors to vote on a proposed plan of arrangement. The initial application to the court under the CCAA is usually done on an ex parte basis (i.e., without notice to the creditors). The stay granted by the court is limited to thirty days on the initial application with a provision for additional applications to be made in order to extend the stay. The Canadian experience indicates that a restructuring under the $C C A A$ usually takes six to twelve months to accomplish. The debtor company must establish due diligence and good faith in respect of its efforts to

$3 \quad$ L.W. Houlden \& G. Morawetz, The 1999 Annotated Bankruptcy and Insolvency Act (Toronto: Carswell, 1998) at 924.

- U.S.B.C. 11 (West Group, 1998); 11 U.S.C. (1978). 
carry out a successful restructuring in order to obtain a continuance of the stay. However, a creditor or group of creditors can, at any time while the stay of proceedings is in effect request that the stay be terminated, either specifically with respect to certain collateral or generally, if the creditors can establish prejudice.

The Norcen Energy v. Oakwood Petroleum case ${ }^{s}$ is the leading judgment regarding the court's power to grant a stay of all proceedings against a debtor company under the $C C A A$. Justice Forsyth interpreted s. 11 of the $C C A A$ in a manner consistent with the overall purpose of the $A c t$ and concluded that the Court had the jurisdiction and power to stay contractual rights of parties who were not even creditors of the debtor company where the exercise of contractual rights by non-creditors could jeopardize a successful restructuring under the $C C A A$. In that case, the $C C A A$ stay applied to prevent the removal of the debtor as operator under an operating agreement.

A proposed plan of arrangement can deal with secured and unsecured creditors, and the $C C A A$ may be used in conjunction with corporate legislation to propose a plan of arrangement with the shareholders of the debtor company. Under the 1997 amendments, ${ }^{6}$ a plan of arrangement may now include compromises of claims against the directors of the debtor company.

Creditors vote in separate classes according to the similarity of their interests. For example, all secured creditors may vote as one class and all unsecured creditors may vote as another. Voting provisions in the CCAA now mirror those of the Bankruptcy and Insolvency Act. $^{7}$ This means that creditors representing a majority in number and twothirds in dollar value of all creditors in the class voting in person or by proxy must accept the proposed restructuring or plan of arrangement in order for the restructuring to proceed. Once the plan of arrangement is approved by the requisite majority of each class of creditors and is sanctioned by the court, the plan will be binding on all creditors dealt with under the plan.

\section{B. APPLICABILITY OF THE CCAA}

The $C C A A$ applies to companies incorporated under provincial legislation or under the Canada Business Corporations Act. ${ }^{8}$ It can also apply to any non-Canadian corporation with assets in Canada or doing business in Canada. For example, an American corporation carrying on business in Canada could apply for relief under the $C C A A$ with or without making a simultaneous filing under chapter 11 of the United States Bankruptcy Code. Recently in Alberta a successful restructuring case involving Solv-Ex Corporation occurred whereby the CCAA and chapter 11 of the US Bankruptcy Code were used simultaneously. ${ }^{9}$ In these proceedings there were twelve joint hearings between the United

[1989] 2 W.W.R. 566 (Alta. Q.B.) [hereinafter Norcen Energy].

S.C. 1997 , c. 12.

R.S.C. 1985 , c. B-3 [hereinafter $B I A$ ].

R.S.C. 1985 , c. C-44.

There is no reported decision authorizing the cross-border protocol. Solv-Ex is an example of a crossborder insolvency. 
States Bankruptcy Court at New Mexico and the Court of Queen's Bench of Alberta at Calgary.

In order to apply for relief under the $C C A A$, the debtor company must have at least $\$ 5$ million in debt and must:

(1) be bankrupt or insolvent and must admit to its insolvency in its application;

(2) have committed an act of bankruptcy within the meaning of the $B I A$, or be deemed insolvent within the meaning of the Winding-up and Restructuring $A c t ;^{10}$

(3) have made an authorized assignment or must have against it a receiving order made under the $B I A$; or

(4) be in the course of being wound up under the Winding-up and Restructuring Act because the company is insolvent.

Prior to the 1997 amendments to the $C C A A$ another significant requirement existed, namely that the debtor company have an outstanding issue of secured or unsecured bonds, debentures, debenture stock, or other evidence of indebtedness issued under a trust deed or other instrument running in favour of a trustee. This requirement was eliminated in 1997.

\section{THE ROLE OF THE MONITOR}

Where a stay order is granted under s. 11 of the $C C A A$, the appointment of a monitor is mandatory. In general, licensed trustees in bankruptcy are appointed as monitors in $C C A A$ proceedings. The monitor has the following rights and duties:

(1) in order to properly assess the debtor company's business and financial affairs, the monitor is given access to the debtor company's property, including the premises, books, records, data, and other financial documents of the company;

(2) the monitor must file a report with the court on the state of the debtor company's business and financial affairs and the court will usually order that the monitor provide reports to it on a monthly or quarterly basis until the creditors have voted on the plan of arrangement;

(3) the monitor must file a report with the court forthwith after ascertaining any material adverse change in the company's projected cash flow or financial circumstances; and

(4) the monitor must carry out other functions in relation to the company as the court may direct. For example, the monitor may be directed to assist the company in devising a plan of arrangement for consideration by the creditors.

Where the monitor acts in good faith and takes reasonable care in preparing the necessary reports, the monitor will not be liable for loss or damage to any person resulting from that person's reliance on the report. 
The debtor company is required to provide such assistance to the monitor as is necessary to enable the monitor to adequately carry out its functions.

Where a monitor carries on business of a debtor company or continues the employment of the company's employees, the monitor will not be personally liable in respect of any claim against the company where the claim arose before or upon the monitor's appointment. In addition, the monitor is not personally responsible for any environmental damage which occurs before or after the monitor's appointment unless it is established that the damage occurred as a result of the monitor's gross negligence or willful misconduct.

\section{Debtor in Possession financing}

Many $C C A A$ cases evidence a chronic need to obtain interim operating financing to keep the debtor company in business. Debtor in possession ("DIP") financing solves this problem but will only be provided by a lender if that lender is assured by way of court order that it will have a first ranking security interest and charge on the assets of the debtor company to secure the interim operating financing. Although there is no statutory basis for the approval of DIP financing, there are now a number of court precedents for such financing. A court, when considering an application for approval of DIP financing, must ensure that all interested creditors have been served with notice of the application.

\section{E. ENVIRONMENTAL CONCERNS}

A claim against a debtor company for costs of remedying any environmental condition or damage affecting real property of the company will be a claim under the $C C A A$, regardless of whether the condition arose, or the damage occurred, before or after the date in which the proceedings under the $C C A A$ were commenced. The $A c t$ also provides a special priority for claims for environmental clean-up. Any claim by the federal or a provincial government against the debtor company for the costs of remedying any environmental condition or for damage affecting real property will be secured by a charge on the real property. This charge is enforceable in the same way as a mortgage on real property. This special environmental clean-up charge ranks above any other claim, right, or charge against the real property of the debtor company. It is often described as a "super priority" charge on the land.

\section{F. Contents of the Plan}

The type of plan of arrangement used by the debtor company will depend to a large extent on the individual circumstances of the debtor company. In the past some plans have followed a similar pattern and have basically provided for the conversion of debt to equity by way of issuance of stock along with the payment of some cash to the creditors.

In some reported decisions, the court has approved plans which simply provided for a sale of assets by the debtor company in exchange for securities and obligations of the 
purchaser." In addition, a plan of arrangement under the CCAA may be used with corporate legislation to facilitate the acquisition of a public corporation by a solvent socalled "white knight."

There is some doubt about whether a plan which simply provides for the liquidation of the assets of a debtor company and the distribution of proceeds generated by the liquidation is a plan which can be adopted under the $C C A A$. The $C C A A$ was created for the purpose of allowing an insolvent company to attempt to remain in business and avoid being liquidated through bankruptcy. If the debtor company wishes to proceed with liquidation, the Winding-up and Restructuring Act or the BIA could be used for this purpose. On the other hand, it can be argued that a straight liquidation plan may be successful under the $C C A A$ where the method of liquidation is different in some respect from that which would occur under the Winding-up and Restructuring Act or the BIA.

In recent decisions in the insolvency of Fracmaster Ltd. both the Alberta Court of Queen's Bench and Court of Appeal expressed the opinion that, while the liquidation of an insolvent company's assets was possible under the $C C A A$, liquidation is not generally an appropriate use of the statute. ${ }^{12}$ Thus it appears that in Alberta there must be a special reason why a liquidation should occur under the auspices of the $C C A A$ rather than under a receivership or bankruptcy.

When creating a plan of arrangement thought should be given to dealing with all creditors in a fair and equal manner so that preference among the creditors is avoided. ${ }^{13}$ In addition, significant income tax consequences must be considered when preparing a plan under the CCAA. For example, it is vital to consider avoidance of the adverse tax consequences arising as a result of any forgiveness of debt issues or of any change of control of the debtor company.

\section{G. Procedural Steps}

The following is a summary of the procedural steps under the $C C A A$ :

(1) An application is made to the court by the debtor company, any creditor, the trustee in bankruptcy or the liquidator of the debtor company for an order declaring that the CCAA applies to the debtor company, and for an order staying for thirty days all proceedings taken or that might be taken in respect of the debtor company, and for an order prohibiting any further actions, proceedings, or suits against the debtor company. Courts will give a wide interpretation to the word "proceeding."

(2) Later applications to the court are made to extend the stay of proceedings until the plan of arrangement is filed and voted on.

See for example, Montreal Trust Company v. Abitibi Power \& Paper Co. (1938), O.R. 589 (C.A.). Re Fracmaster (1999), 11 C.B.R. (4th) 204, affd (1999) 11 C.B.R. (4th) 230 (C.A.).

D.H. Goldman, D.E. Baird \& M.A. Weinczok, "Arrangements Under the Companies' Creditors Arrangement Act" (1991) I C.B.R. 135. 
(3) An application is usually made requesting the court to approve a form of proof of claim which is mailed to the creditors for completion and returned by them to establish the amounts of the claims and their status as either secured or unsecured creditors.

(4) Once the plan of arrangement is ready for filing with the court, an application is made for an order directing that a meeting of the creditors occur and that a copy of the plan, notice of meeting of creditors, proxy, and voting letter be mailed to each of the creditors at their addresses as listed in the records of the debtor company. The order may provide that a notice of the meeting of creditors be published in one or more newspapers.

(5) At the meeting the creditors must vote as separate classes. A majority in number representing two-thirds in value of each class of creditors must approve the plan before it can be sanctioned by the court. ${ }^{14}$

(6) If shareholders are being affected, the required vote for the shareholders will be set out in the specific corporate legislation or the by-laws which apply to the debtor company.

(7) If the plan is approved by the creditors, the plan may then be sanctioned by the court. The court need not sanction the plan even if it has been approved by the required majority of creditors. It is a purely discretionary exercise, and the court may find that the plan is not economically feasible or is not in the best interests of all the creditors. ${ }^{15}$ The court must also be satisfied that all statutory requirements have been complied with, that there has not been any preference payments or transfers of assets to creditors, that creditors have been properly classified for voting purposes, and that voting procedures were properly followed. ${ }^{16}$

(8) Any party or shareholder who objects to the orders or decisions made under the CCAA may apply for leave to appeal under s. 13. This right of appeal is not automatic.

\section{BaCkground of Blue Range Resource Corporation}

Blue Range Resource Corporation ("Blue Range") produced natural gas. In early 1999 it was the subject of a hostile takeover by Big Bear Exploration Ltd. ("Big Bear"). Shortly after the takeover, Big Bear discovered what it later alleged to be false and misleading statements regarding the finances of Blue Range. Because of the financial difficulties of Blue Range, Big Bear, through its control of Blue Range, caused Blue Range to file for protection under the CCAA. On March 2, 1999, Blue Range obtained an order from the Alberta Court of Queen's Bench. The order stayed all proceedings against Blue Range, including the exercise of set-off, and permitted Blue Range to terminate agreements where it deemed such actions appropriate in order to facilitate the financial restructuring. The order also contained other standard provisions under the $C C A A$, including the appointment of a monitor. Eventually a plan of arrangement was placed for approval before Blue Range's creditors. The substance of the plan of arrangement was a sale of what was 
substantially all of Blue Range's assets to Canadian Natural Resources Ltd. The plan of arrangement was approved by Blue Range's creditors and sanctioned by the court.

\section{The SET-OFf, TeRmination OF CONTRACTS, AND DEDICATION OF RESERVES DECISION}

The most important feature of the $C C A A$ is the jurisdiction it gives to the court to stay all proceedings by creditors and non-creditors against the debtor company seeking to restructure. In Meridian Developments v. Toronto-Dominion Bank, ${ }^{17}$ Wachowich J. stated that the purpose of the stay power in s. 11 of the $C C A A$ was to maintain the status quo, to give the debtor company breathing space to develop its restructuring plan, and to prevent creditors from trying to obtain an advantage over other creditors. In his decision in Norcen Energy, ${ }^{18}$ Forsyth J. stated that a broad interpretation must be given to the stay power in s. 11. His interpretation of $\mathrm{s} .11$ included the ability of the court to stay contractual rights of third parties, even if those third parties were not creditors of the debtor company.

More recently, LoVecchio J. of the Alberta Court of Queen's Bench granted an order in Smoky River Coal, ${ }^{19}$ pursuant to which he prevented a third party non-creditor from bringing arbitration proceedings against the debtor company. He ordered that the dispute between the parties be resolved by way of a trial in the CCAA court. This decision was upheld in Luscar Ltd. v. Smoky River Coal, ${ }^{20}$ which confirms the conclusion that the $C C A A$ confers broad powers on the court under $\mathrm{s} .11$ in order to control all proceedings against the debtor company, including non-judicial proceedings such as arbitration proceedings.

Numerous other decisions throughout Canada have supported the conclusion that s. 11 should be given a broad interpretation so that it can be used as an effective tool to facilitate the purpose of the CCAA (i.e., to carry out arrangements or compromises between an insolvent corporation and its creditors). ${ }^{21}$

On June 18, 1999, Justice LoVecchio issued a decision in the Blue Range proceedings $^{22}$ that dealt with the applicability of set-off under $C C A A$ proceedings, the ability of the debtor company to terminate unwanted contracts during the $C C A A$ stay, and the effect of "dedication of reserves" provisions in gas marketing or aggregating contracts. The issue of set-off has been contentious, not only in $C C A A$ proceedings, but also in bankruptcy cases. This is so notwithstanding that both statutes provide for the applicability of "the law of set-off."

(1984), 52 C.B.R. 109 (Q.B.).

Supra note 5.

[1999] A.J. No. 272 (Q.B.), online: QL (AJ).

[1999] A.J. No. 185 (C.A.), online: QL (AJ).

See e.g., Timber Lodge Lid. v. Timber Lodge Lid. (Creditors of) (1992), I5 C.B.R. (3d) 244 (P.E.I.

T.D.); Diemaster Tool Inc. v. Skvortsoff (Trustee off (1991), 3 C.B.R. (3d) 133 (Ont. Gen. Div.); Nvoa Metal Products Inc. v. Comisky (Trustee of) (1990), I C.B.R. (3d) 101 (Ont. C.A.).

Blue Range Resource Corp. (1999), 245 A.R. 154 (Q.B.). 


\section{A. Legal AND EQuitable Set-OFF}

Generally there are two types of set-off: legal set-off and equitable set-off. Both are described in the leading case of Telford $v$. Holt ${ }^{23}$ Legal set-off requires cross debts which are mutual (i.e., between the same parties and in the same capacity). In $R e$ Northland Bank ${ }^{24}$ the court held that "mutual debts" were debts due from either party to the other for liquidated sums or money demands which can be ascertained with certainty at the date of bankruptcy. Each party must have the right to enforce its claim at the date of bankruptcy, and if one party cannot do so there is no right of legal set-off.

Because legal set-off requires a liquidated debt, it does not exist for a claim in damages, even if the parties have provided a formula in a contract for calculating the damages or if the industry provides such a formula. ${ }^{25}$

Equitable set-off arises where there is no legal set-off, but where there is a relationship between the claims of the parties such that it would be unconscionable or inequitable not to permit set-off. ${ }^{26}$ Equitable set-off can apply where mutuality is lost or never existed so long as the cross obligations are closely related. ${ }^{27}$ It is available where there is a claim for money whether the claim is liquidated or unliquidated. ${ }^{28}$ In at least one case the court held that, for equitable set-off to apply, the creditor asserting such a claim must have, at the date of bankruptcy, an entitlement to a remedy in its own right. ${ }^{29}$

The argument of parties seeking set-off in insolvency proceedings is based on the perceived injustice for a person who has mutual dealings with an insolvent person of having to pay in full what is owed while having to be content with a dividend on what the insolvent person owes. Those opposing set-off point out that the effect of set-off is to prefer one creditor over the general body of creditors, as the exercise of set-off secures the claim of the party entitled to set-off to the extent of the amount set off.

\section{B. The FACTS Before Justice LoVeCCHIO}

Blue Range entered into a number of long-term natural gas supply agreements with various gas marketing companies. Shortly after entering into $C C A A$ proceedings the contracts with the gas purchasers were terminated by Blue Range. At the time the purchasers were indebted to Blue Range for previous gas deliveries. Upon termination of the contracts, the same purchasers had damage claims for loss of profit as they were then required to purchase replacement gas at higher prices. The contracts typically contained a formula for calculation of such damages.

[1987] 2 S.C.R. 193 [hereinafter Telford].

(1994), 25 C.B.R. 166 (Man. Q.B.).

Citibank Canada v. Confederation Life Insurance Co. (1996), 42 C.B.R. 288 (Ont. Gen. Div.).

Telford, supra note 23.

CIBC v. Tuckerr Industries and Benyan \& Co. (1983), 149 D.L.R. 172, 48 C.B.R. I (B.C. C.A.). Aboussafy v. Abacus Cities Lid. (1981), 39 C.B.R. 1 (Alta. C.A.).

Re Northland Bank, supra note 24. 
The initial order obtained by Blue Range in the $C C A A$ proceedings contained typical stay provisions, including a stay of all set-off rights. The gas purchasers applied to the court for an order lifting the stay and permitting the purchasers to set off amounts owing to Blue Range against the damage claims. Because the damage claims were far greater than the amounts owing for previous gas deliveries, the net result would have been the complete elimination of the receivables of Blue Range from such gas purchasers.

\section{THE SET-OfF AMENDMENT}

As part of the $1997 C C A A$ amendments s. 18.1 was enacted. It provides that

[t]he law of set off applies to all claims made against a debtor company and to all actions instituted by it for the recovery of debts due to the company in the same manner and to the same extent as if the company were plaintiff or defendant, as the case may be. ${ }^{30}$

The first case to discuss set-off since the $C C A A$ amendments and enactment of s. 18. 1 was the Blue Range decision of June 18, 1999, by Justice LoVecchio. ${ }^{31}$

\section{QUINTETTE COAL}

Prior to the amendments, the law regarding set-off in CCAA proceedings was established in Quintette Coal v. Nippon Steel Corp. ${ }^{32}$ In that case a debtor company owned a coal mine which sold coal to a Japanese fuel conglomerate. The debtor company obtained CCAA protection with a stay order that prevented the conglomerate from exercising rights of set-off. The conglomerate wanted to set off amounts owed by it for coal received after the $C C A A$ proceedings were commenced against the pre- $C C A A$ amount owed by Quintette. The conglomerate applied to vary the stay to allow set-off. Thackray J. stated the following:

Nor do I accept the proposition that the order forces an overpayment by J.S.I. for future coal deliveries. They are obliged to pay, and Quintette is obliged to accept, a price set pursuant to the arbitration award or any variation thereof pursuant to any appeal of that award [the damages owed by the debtor company]. This award has created a debt owed by Quintette to J.S.I. and I see that as completely distinguishable from the debts incurred by J.S.I. for future coal deliveries.

Mr. G. Muench, in his short but able presentation, said that he could not see why J.S.I. should be treated any differently than any other creditor of Quintette. In spite of the able arguments of Mr. McAlpine, neither can 1 . 
[U]nless there is a sound legal principal for doing so, I must not carve out one portion of the order and give an advantage to one creditor over another. ${ }^{33}$

In essence, Thackray J. observed that the allowance of set-off provided one creditor with a full recovery (to the extent of the set-off). This was seen as creating an unfair advantage vis-à-vis other creditors. The British Columbia Court of Appeal affirmed the chambers judge's decision and confirmed that the power to stay set-off rights existed under s. 11 of the $C C A A .^{34}$

\section{E. The Decision of Justice LoVecchio}

In the June 18, 1999, Blue Range Resource Corp. decision ${ }^{35}$ the gas purchasers argued that the new s. 18.1 of the CCAA had the effect of nullifying the Quintette decision. Justice LoVecchio accepted this argument, at least in part. While he was inclined to agree that allowing set-off runs contrary to the purpose of the $C C A A$ by allowing one creditor an unfair advantage, in view of s. 18.1, he could not consider that reason as a ground for disallowing set-off. He held that, as a result of s. 18.1, he was obliged to apply "the general law of set-off' to debts owed or claimed by the debtor company.

The parties acknowledged that they sought equitable set-off, not legal set-off. Accordingly, Justice LoVecchio considered the following five principles set out in Telford:

(1) The party relying on a set-off must show some equitable ground for being protected against his adversary's demands;

(2) The equitable ground must go to the very root of the plaintiff's claim before a set off will be allowed;

(3) A cross-claim must be so clearly connected with the demand of the plaintiff that it would be manifestly unjust to allow the plaintiff to enforce payment without taking into consideration the cross-claim;

(4) The plaintiff's claim and the cross-claim need not arise out of the same contract; and

(5) Unliquidated claims are on the same footing as liquidated claims. ${ }^{\text {"W }}$

The gas purchasers argued that it would be manifestly unfair to allow Blue Range to recover amounts owing from the gas purchasers without taking into account damages owed by Blue Range to the same purchasers. However, after a review of the case LoVecchio J. determined that the real question to be asked was

[w] hether the anticipated damages are so closely connected to the payments for February and March natural gas that it would be manifestly unjust or unfair to require Duke and Engage [the gas purchasers]

Ibid. at 296.

(1990), 2 C.B.R. (3d) 303 (B.C.C.A).

Supra note 22.

Supra note 23 at 212. 
to pay Blue Range for the natural gas without permitting Duke and Engage to set off their claims for unliquidated damages. ${ }^{37}$

LoVecchio J. held that the prospective unliquidated damages claims of the gas purchasers were not sufficiently connected to the pre-existing outstanding accounts for the purchase of gas to give rise to set-off, despite the fact that they arose under the same master contracts. As he stated:

Fundamentally, Engage and Duke contracted to buy natural gas from Blue Range. They contracted to pay for it on a month to month basis. They were delivered natural gas. They accepted the natural gas delivered and have sold or otherwise utilized the natural gas received.

Now, when payment is due they do not want to pay for it. The reason they give is that Blue Range's suspension of future deliveries will make them incur future damages. In my view, the future damages from the non-deliveries are sufficiently independent that it is not manifestly unjust to require Engage and Duke to pay for the natural gas that they have received. ${ }^{38}$

LoVecchio J. further noted that in the Quintette case the purchaser wanted to set off past debts of the insolvent company against its future obligation to pay the insolvent company for ongoing coal deliveries. While that situation was the inverse of the situation before him, LoVecchio J. held that the principle was the same. The observation by Thackray J. that the debt owed by Quintette to J.S.I. was distinguishable from debts incurred by J.S.I. for future coal deliveries was not affected by the change in the CCAA provisions regarding set-off.

LoVecchio J. concluded that because the anticipated damages arose after the completion of the deliveries and after the stay order, they were unsecured claims like those of all other unsecured creditors. He held that the damage claims were not sufficiently related to the deliveries of gas prior to the $C C A A$ proceedings to separate them from other unsecured debts.

\section{F. The Decision of THE COURT OF APPEAL}

The gas purchasers appealed the decision of Justice LoVecchio. By the time the appeal was heard on April 13,2000, the major secured creditors, who had successfully opposed the gas purchasers before Justice LoVecchio, had been paid out as a result of Blue Range's plan of arrangement. Accordingly, only an independent counsel appointed by the monitor of Blue Range for the sole purpose of opposing the gas purchasers at the Court of Appeal represented an opposing viewpoint to the gas purchasers.

The Court of Appeal reversed the decision of Justice LoVecchio. The Court of Appeal considered the Telford v. Holt and Quintette Coal decisions as well as the 1997 set-off amendment, s. 18.1 of the $C C A A$. It said, of that provision: 
This section was added to the $C C A A$ in 1997 and the Chambers Judge recognized that even if the application of set-off had the result of preferring one creditor over others, parliament, by enacting s. 18.1 made the decision that the general law of set-off is to apply in CCAA proceedings. It is apparent that the Chambers Judge had difficulty with this concept and was clearly of the view that allowing set-off was contrary to the purposes of insolvency legislation. He did. however, appear to instruct himself that this consideration should not carry any weight due to the addition of s. 18.1....

While the Chambers Judge recognized the set-off was available in principle, in the end, policy considerations regarding the priority of creditors appear to have influenced his decision. ${ }^{39}$

The Court of Appeal held that while the chambers judge recognized that the priority of creditors should be relevant in the face of s. 18.1, he did not act on that recognition. The Court went on to consider the case of Cam-Net Communications v. Vancouver Telephone Co., a decision which was not available to Justice LoVecchio. ${ }^{40}$ In that case the British Columbia Court of Appeal upheld a creditors' right to set-off in CCAA proceedings where the party claiming set-off alleged that the insolvent company had breached its contract by failing to provide services of a sufficient quality. It held that the claim was so closely connected to the cross-claim of the insolvent company that it would be inequitable to permit the insolvent company to collect its debt while preventing the other party from claiming set-off.

The Court concluded that the close connection of the transactions in the Blue Range case made it unjust to require the gas marketers to pay the cost of the pre-CCAA deliveries in view of the fact that they would suffer significant losses due to the early termination of the same contract. The Court also held that the fact that the damages owed to the gas purchasers arose after the stay order was granted was not relevant when the obligations arose out of the same contract. In the end, the Court of Appeal's decision may be boiled down to the concept that claims arising out of the same contract will likely be subject to equitable set-off in $C C A A$ proceedings.

\section{G. IMPACT OF THE SET-OFf Decision}

The decisions of LoVecchio J. and the Court of Appeal establish that the general law of set-off will apply notwithstanding a CCAA stay of proceedings. Creditors wishing to enjoy a set-off will have to apply to the court to permit the set-off, as the typical initial $C C A A$ order will contain a blanket prohibition against set-off. The decision of LoVecchio J. reflects the commonly found reluctance of the courts to allow a set-off, as previously evidenced in Quintette. Apparently it will require an extremely close connection between the debts owing from and to the debtor company in order to apply set-off.

The decisions give rise to two points of discussion. First, both LoVecchio J. and the Court of Appeal approached the question of set-off from the perspective of whether to permit the exercise of set-off. They did not specifically address the question of whether s. 11 in itself gave the court the power to stay the exercise of set-off. It is unclear whether 
the court concluded, on the basis of s. 18.1, that it could not stay set-off and let the debtor company deal with set-off in a plan of arrangement (i.e., by providing for a higher recovery for parties with valid rights of set-off). Accordingly, the case left open the question of whether an initial order obtained under s. 11 of the CCAA can contain a provision staying set-off. It is suggested that, notwithstanding s. 18.1 of the $C C A A$, it is still within the court's jurisdiction to stay set-off in an initial order. Several reasons exist for such a conclusion.

First, s. 18.1 does not expressly prohibit the staying of a right of set-off. The section merely states that the law of set-off applies to claims made against a debtor company and to all actions instituted by that debtor company. In this case, no action had been instituted by Blue Range against the parties claiming a set-off. Rather, the gas purchasers argued that they could merely withhold payment of accounts receivable on the basis of set-off.

Second, s. 11.1 of the $C C A A$ also supports the proposition that s. 18.1 does not prohibit a stay of the right of set-off. Under s. 11.1 certain contracts, called "eligible financial contracts," are exempted from stays. In particular, s. 11.1(3) provides that, notwithstanding any stay, parties to an eligible financial contract can exercise a right of set-off. Surely this provision would not be necessary if the effect of s. 18.1 was to prohibit a staying of a right set-off in any event. On this point, it is important to note that s. 11.1 and s. 18.1 were enacted in the same amendment to the $C C A A$.

Further, the case raises the issue of the general availability of set-off in proceedings regarding oil and gas company restructuring. As mentioned above, there is at least one case which states that, in bankruptcy, a creditor asserting a claim to equitable set-off must at the date of bankruptcy have an entitlement to the remedy. ${ }^{41}$ Translated to $C C A A$ proceedings this indicates that, for equitable set-off to apply, the right of set-off must exist at the date of the institution of CCAA proceedings. In the case of the gas purchasers in the Blue Range case, the claim for damages did not arise until after the institution of $C C A A$ proceedings when the contracts in question were terminated. It appears that the reasoning of Justice LoVecchio follows the same logic, a logic which the Court of Appeal ignored. Several prominent insolvency practitioners have questioned the decision of the Court of Appeal in this regard.

Based on the foregoing, in oil and gas restructuring under the $C C A A$ the exercise of set-off by parties with whom the debtor oil and gas company deals can be stayed under an initial order. In most cases parties to such contracts will not be able to set off amounts owing under damage provisions for failure to deliver in the future against amounts owing for deliveries which occurred prior to the institution of $C C A A$ proceedings because the contract will not be terminated until after the $C C A A$ proceedings commence.

Finally, it is apparent that both Justice LoVecchio and the Court of Appeal held that, in considering the application of equitable set-off, the fact that a party exercising set off obtains a de facto security interest was irrelevant. However, this fact should be one of the 
"equities" involved in the decision making process. Is it equitable that a creditor obtain priority over other creditors simply because it also owes money to the debtor?

The set-off issue is very important to insolvency practitioners. If set-off of such damage claims is not stayed, parties to oil and gas purchase contracts will be able to hold outstanding receivables ransom against further unliquidated damages for breach of the debtor companies' failure to deliver. Such a reduction in cash flow would prejudice any attempt at restructuring. Further, a lack of the ability to stay set-off would grant all parties with purchase and sale contracts a de facto security interest to the prejudice of ordinary trade creditors.

It should be noted that the case does not deal with legal set-off. Accordingly, where a creditor seeks to set off two liquidated amounts different considerations may arise.

\section{H. THE TERMINATION OF CONTRACTS ISSUE}

As mentioned, two additional issues were considered in the June 18, 1999, decision. The first was the ability to terminate contracts, and the second was what conditions were required for the exercise of that ability. As discussed in the overview of the $C C A A$ above, $C C A A$ orders often contain a provision permitting the debtor company to terminate contacts. The company can thereby rid itself of uneconomical contracts during the restructuring process. Of course, this will result in a claim (usually unsecured) by the other contracting party, which is included in the plan of arrangement.

In Justice LoVecchio's decision certain parties with contracts challenged the ability of Blue Range to terminate contracts and sought an amendment to the initial order, either preventing such termination or providing that termination could only occur where Blue Range could demonstrate that termination was necessary for the success of the restructuring.

After reviewing the jurisprudence, Justice LoVecchio held that including the termination provision was within the court's power under the CCAA. Further, he declined to put any limitations on such ability. In so doing, he favoured the interest of flexibility of the debtor company during the restructuring process over the rights of other parties to specific performance of their contracts.

\section{The Dedication OF Reserves IsSue}

Finally, the June 18,1999, decision dealt with provisions in some marketing and aggregating contracts whereby Blue Range dedicated certain gas reserves to the fulfillment of the contract. Some of the contracts also provided that the gas interests of Blue Range containing such reserves could not be sold without ensuring that the purchaser assumed the dedication obligations. The gas aggregator argued that these provisions had to be honoured if the gas interests of Blue Range were sold as part of the $C C A A$ process. It was argued that the provisions had the effect of creating an interest in land. 
Justice LoVecchio reviewed the provisions in question and determined that they did not contain language sufficient to create an interest running with the land. Instead, he held that they were merely an indication or promise that Blue Range had sufficient reserves to meet its delivery obligations under the contract. While Justice LoVecchio's decision is, at first glance, not favourable to gas marketers or aggregators, it does suggest that, with appropriate language, a court might find that a dedication provision creates an interest in land. Arguably, such an interest would have to be registered as an encumbrance at the appropriate land titles or mines and minerals registry.

\section{Eligible financial Contracts}

\section{A. BACKGROUND}

As mentioned, Blue Range was a producer of natural gas and it entered into a number of natural gas supply agreements with several gas marketing companies. These contracts did not take the form of the standard International Swaps and Derivatives Association Contract ("ISDA") commonly used in financial contract arrangements such as hedges or swaps. The initial $C C A A$ order in the Blue Range proceedings contained the usual provision that restrained third parties from terminating their agreements with Blue Range. The wording of the provision was as following:

[A]ll persons having arrangements or agreements, written or oral, with Blue Range for the supply of goods and/or services by or to Blue Range ... are hereby restrained from accelerating, terminating, suspending, modifying or cancelling any such agreements, arrangements or supply of goods or services, and are also hereby restrained from exercising any right of distress, recission [sic], set-off or consolidation of accounts in relation to any indebtedness or obligation in favour of Blue Range ... without the prior written consent of Blue Range ... or leave of this Honourable Court. ${ }^{42}$

At the same time the order authorized Blue Range to terminate agreements where it deemed it appropriate to do so in order to facilitate its financial restructuring. Blue Range was authorized to make provisions for the consequences of such terminations in its plan of arrangement with its creditors. Arguably Blue Range did not need such an authorization from the court and could have elected to terminate whatever contracts it thought it needed to terminate in order to successfully restructure its affairs. The obvious downside to such a decision is the third party claims for damages that would consequentially arise. Such claims would need to be included with all other creditor claims in the Blue Range plan of arrangement.

Blue Range wanted to sell certain oil and gas leases to raise cash to carry out a plan, and in order to maximize the value it needed to sell those leases free and clear of any contractual commitments for the sale of gas from the leased properties at less than market rates. In some cases Blue Range had contracts for the sale of natural gas to third party marketers and also had purchase contracts with the same parties. As well, some of the supply contracts were at a price which was favourable to Blue Range; whereas others were 
at a price below market value. Blue Range would naturally want to terminate those contracts which were below market value but keep in place those above market price.

Three gas marketers that dealt with Blue Range claimed that their gas contracts constituted "eligible financial contracts" which they could automatically terminate because of Blue Range's insolvency. They also claimed that they had rights of set-off which they could apply to reduce the amount owed to Blue Range for natural gas supplied to them prior to the commencement of the CCAA proceedings. They relied on 1997 amendments to the $C C A A$ in support of their position. On June 30,1999 , Justice LoVecchio issued his decision. ${ }^{43}$

\section{B. The Eligible financial Contract amendment}

The focus of the June 30,1999, decision was the 1997 amendment that added s. 11.1 dealing with eligible financial contracts. Section 11.1 states that an "eligible financial contract" means the following:

(a) a currency or interest rate swap agreement,

(b) a basis swap agreement,

(c) a spot, future, forward or other foreign exchange agreement,

(d) a cap, collar or floor transaction,

(e) a commodity swap,

(f) a forward rate agreement,

(g) a repurchase or reverse repurchase agreement,

(h) a spot, future, forward or other commodity contract.

(i) an agreement to buy, sell, borrow or lend securities, to clear or settle securities transactions or to act as a depositary for securities,

(j) any derivative, combination or option in respect of, or agreement similar to, an agreement or contract referred to in paragraphs (a) to (i),

(k) any master agreement in respect of any agreement or contract referred to in paragraphs (a) to (j),

(l) any master agreement in respect of a master agreement referred to in paragraph (k),

(m) a guarantee of the liabilities under an agreement or contract referred to in paragraphs (a) to (l), or

(n) any agreement of a kind prescribed."

Section 11.1(2) states that "[n]o order may be made under this Act staying or restraining the exercise of any right to terminate, amend or claim any acceleratedpayment under an eligible financial contract." ${ }^{14}$ Thus the new amendments created an exception to the broad stay power given to the court under s. 11; the court could not prevent the early termination of eligible financial contracts. In addition, under s. 11.1(3), where an eligible financial contract is terminated, the setting off of obligations by the other party to the eligible financial contract with the debtor company is permitted in accordance with its provisions.

Blue Range Resource Corp. (1999), 245 A.R. 172 (Q.B.)

CCAA, supra note 1.

Ibid., s. II.I(2). 
In this Blue Range case the three gas marketers claimed their gas contracts (which were simple supply contracts pursuant to which gas would be delivered to the marketers in return for payment of a purchase price, which would either be fixed or tied to an index over a specified term) were "forward commodity contracts" within the meaning of s. 11.1(h). They argued that these contracts could be terminated as a result of Blue Range's insolvency and that their set-off rights under those contracts could not be restrained by the court.

\section{History OF THE Eligible Financial CONTRACT AMENDMENT}

Sections 65.1(a) and (9) of the $B I A$ contain similar language to that in s. 11.1 of the $C C A A$. The $B I A$ was amended in 1992 to include the eligible financial contract provisions. ${ }^{46}$ The $C C A A$ was similarly amended in $1997 .{ }^{47}$ Justice LoVecchio's decision appears to be the first time in Canada that the eligible financial contract amendments have been interpreted. Members of the Canadian Bankers Association lobbied for the amendments, and their submissions in favour of the amendments included the following statements:

A very important issue relating to commercial insolvencies is the status of financial hedging contracts in these insolvencies. We realize that this may appear to be a fairly technical issue to members of this committee. We want to assure you that it is of vital concern to the financial community as a whole, not just ourselves.

A recent amendment to Chapter 11 of the U.S. Bankruptcy Code does permit counter-parties to terminate or close out hedging contracts during a stay period if one of these becomes insolvent. Similar legislation we feel is needed in Canada to ensure the continued competitiveness of Canadian financial markets and their ability to be part of these contracts when the other party is in fact a U.S. entity or a U.S. citizen.

The contracts being discussed, which we have called eligible financial contracts, are, however, important in their limited sphere. They help Canadian and other corporations world wide to manage risks such as changes in interest rates and in currency exchange rates.

In the United States the solution we propose has been adopted, as an exception to their very pro-debtor legislation. It has enabled troubled U.S. debtors, and especially those in the financial community, to continue to be able to access these risk-controlling markets at a time when they have needed such protection the most. ${ }^{48}$

The Standing Committee on Consumer and Corporate Affairs and Government Operations requested that Parliament consider the eligible financial contract amendment to the $B I A$ and stated:

4. S.C. 1992, c. 27.

47 Supra note 6.

4* "Proceedings of the Standing Senate Committee on banking, trade and commerce" (4 November 1996). 
The Committee heard from the Canadian Bankers Association that it wants to be able to terminate certain classes of financial transactions in the event of the filing of a notice of intention. This suggestion relates to a variety of financial swap and hedging arrangements.

The recommendation by the Committee was as follows:

The Government give due consideration to including a provision in Bill C-22 that would allow certain financial swap and hedging agreements to be terminated where a notice of intention or a proposal has been filed. ${ }^{49}$

The eligible financial contract amendment to the $C C A A$ was made in 1997 to harmonize the $C C A A$ with the $B I A$.

\section{The Consequences of a finding in Favour of the Gas Marketers}

Oil and gas producers make their corporate living by selling the oil and gas produced by them on their properties. Their cash flows are primarily derived from production sales agreements. On the settlement date, the twenty-fifth of each month, the producers are paid for the oil or gas delivered by them in the preceding month. A court decision holding that contracts for the physical delivery of oil or gas constitute eligible financial contracts that could be terminated (thereby giving rise to rights of set-off not subject to the court's stay of proceedings power under s. 11) would have dire consequences for companies attempting to restructure their financial affairs with their creditors. Unrestrained rights of set-off would significantly reduce cash flow and weaken any restructuring efforts. This decision was important to both the oil and gas business and to the financial institutions which lend to this business sector.

\section{E. Primary ARguments for the GaS MARKETERS}

The gas marketers argued that their gas contracts with Blue Range were forward commodity contracts under s. 11.1(c) of the CCAA as they included the following essential elements:

(1) an agreement between at least two parties;

(2) concerning a tradeable object;

(3) with respect to point in the future.

Due to the existence of these essential elements their gas contracts were forward commodity contracts and therefore eligible financial contracts. They also argued that the phrase "forward commodity contract" has a technical meaning in the oil and gas industry. They relied on the following definition. It is

a customized contract to buy or sell a commodity for delivery at a certain future time for a certain price.

It is customized by individual negotiations between two parties, rather than standardized and traded on 
a board of trade. The parties to the forward contract usually know each other, and in most cases the contract is settled by actual delivery of the commodity. ${ }^{50}$

The gas marketers also argued that the purpose of the amendment to the $C C A A$ was to protect financial and risk management arrangements entered into by contracting parties and that the gas contracts with Blue Range, beyond being simple physical delivery contracts, were being used by Blue Range as a financial risk management tool.

\section{F. The ARguments Against the Gas Marketers}

Courts have held that the $C C A A$ is to be given a liberal and purposeful interpretation, which correspondingly requires a narrow interpretation of provisions creating exceptions to the stay of proceedings in s. 11. In Re Smith Brothers Contracting the court said of an application regarding s. 11.3 of the $C C A A$ that provides an exemption from $C C A A$ stays for "persons ... requiring immediate payment for goods, services, leased or licensed property or other valuable consideration provided after the order is made":

I approach Section 11.3(a) with that spirit, that is, with the perspective that a liberal construction which furthers the policy objectives of the Act will dictate a narrow construction of the types of arrangements which are excepted from a stay order under Section 11.3(a). I underline, however, that any such construction must be intellectually defensible on the basis of the words which Parliament has used in the Section - I am not to redraft the Section in the guise of construing it. ${ }^{51}$

The submissions that were made by the Canadian Bankers Association when the amendments to the $B I A$ were being considered suggest that the focus of the amendments was to protect parties to financial hedging instruments and similar risk management tools. $^{52}$ The minutes of the Parliamentary Standing Committee, which considered the amendments, indicate that the types of transactions that were intended to be protected were "a variety of financial swap and hedging arrangements." ${ }^{53}$ These materials reveal that Parliament was concerned with protection of financial tools with no mention being made of simple contracts for the sale and delivery of commodities such as natural gas.

\section{G. United States BankRUPtCy CODE}

As disclosed in the submissions of the Canadian Bankers Association, when the amendments were being considered the exemptions for eligible financial contracts in the $B I A$ and $C C A A$ were enacted in part to respond to similar provisions under the United States Bankruptcy Code. ${ }^{54}$ Section 362(b) of the United States Bankruptcy Code exempts some instances of set-off from the automatic stay of proceedings under chapter 11:

M. Haedicke \& A. Aronovitz, "Gas Commodity Markets" in D.J. Muchow \& W.A Morgel, eds., Energy Law Transactions (New York: Matthew Bender \& Co., 1990).

(1998), 53 B.C.L.R. 264 at 272.

Supra note 48.

Supra note 49.

Supra note 4, ss. 362(b), 101. 
[S]et off by a commodity broker, forward contract merchant, stock broker, financial institutions or securities clearing agency of any mutual debt and claim under or in connection with commodity contracts, as defined under section $\mathbf{7 6 1}$ of this title, forward contracts, or securities contracts, as defined in section $\mathbf{7 4 1}$ of this title, that constitutes the set off of a claim against the debtor for a margin payment, as defined in section 101, 741 or 761 of this title, or settlement payment, as defined in section 101 or 741 of this title, arising out of commodity contracts, forward contracts or securities contracts against cash, securities, or other property held by or due from such commodity broker, forward contract merchant, stock broker, financial institutions, or securities clearing agency to margin, guarantee, secure, or settle commodity contracts, or securities contracts. 35

Section 362(b) of the Code describes a limited group of parties that would be entitled to an exemption from the stay. These parties are limited to those who engage in the trading of securities or security-like instruments. For example, the definition of "forward contract merchant" in s. 101(26) of the Code is

a person whose business consists in whole or in part of entering into forward contracts as or with merchants in a commodity, as defined in Section 761(8) of this title, or any similar good, article, service, right, or interest which is presently or in the future becomes the subject of dealing in the forward contract trade.

The United States Bankruptcy Code defines a forward contract in s. 101(25) as

a contract ... for the purchase, sale, or transfer of a commodity ... or any similar good, article, service, right, or interest which is presently or in the future becomes the subject of dealing in the forward contract trade, or product or bi-product thereof, with a maturity date of more than two days after the date the contract is entered into, including, but not limited to, a repurchase transaction, reverse repurchase transaction, consignment, lease, swap, hedge transaction, deposit, loan, option, allocated transaction, unallocated transaction, or any combination thereof or option thereon. ${ }^{57}$

\section{H. The Decision of Justice LoVecchio in BLUE RanGe CoRp. ${ }^{58}$}

In the decision the issue was stated by Justice LoVecchio as follows: "The question is simply whether the master firm agreements are financial in nature or are simple supply contracts." Justice LoVecchio found that the inclusion of the word "financial" in the phrase "eligible financial contracts" was very significant. He adopted the approach of giving the section a purposeful meaning in light of the statute as a whole. The issue of whether the contracts were "physical" or "financial" in nature would be resolved by determining the intention of the parties at the time they entered into the contracts. He stated: 
Simply put, if the purpose of the contract is to lead to the actual delivery of the commodity then you do not have a contract which is financial in nature but one which is physical and it should not be found to be an 'eligible financial contract.' If the purpose of the contract is only financial in nature and is not intended to lead to the actual delivery of the commodity, then you have a contract which is financial in nature and not physical and it should be found to be an "eligible financial contract. ${ }^{60}$

He concluded that the contracts in question were ordinary supply of goods contracts, which were physical and not financial in nature. He was not satisfied that all of the contracts formed part of a risk management scheme which involved related hedge or swap agreements for each of the physical contracts.

Most importantly, Justice LoVecchio interpreted the amendment to the $C C A A$ in light of the stated objective of the $A c t$, which is to facilitate compromises and arrangements between debtor companies and their creditors. He explained as follows:

If I were to hold that they were "eligible financial contracts" would this create the problem that the Monitor and the secured lenders envisage, namely that it would defeat the object of the CCAA stay? In my view, it would and $I$ decline to find them "eligible financial contracts." The intent of the legislature was only to protect those future, forward or other commodity contracts which are financial in nature and these are not such contracts. This is because the intent of the parties when the master firm agreements were made was that they would be primarily "physical" contracts. ${ }^{61}$

\section{The Decision Of the Court of APPEAL in BLUE RANGE CORP.}

The decision of Justice LoVecchio was appealed by the gas purchasers. As with the setoff appeal, the secured lenders of Blue Range, who had successfully opposed the gas purchasers before LoVecchio J., did not take part in the appeal, having been paid as a result of the successful plan of arrangement of Blue Range.

The Court of Appeal accepted that the definition of "Forward Commodity Contracts," as urged by the gas purchasers, was merely "contacts to buy or sell an asset at a certain price on a future date." It noted that the long-term natural gas supply contracts in question fit within that general description.

The Court of Appeal considered the importance of hedging and netting in the risk management of gas marketers as well as the place of long-term cash settled and physically settled commodity contracts in the global derivatives market. It accepted the proposition that an "effective and fully functional termination, netting and set off scheme that applies to all derivative instruments, including forward commodity contracts, is critical to the vitality of the derivatives market." 62 The Court of Appeal also noted that the effect of the CCAA stay provisions permitted the insolvent company to terminate and breach contracts with impunity, forcing a non-defaulting party to claim damages as an unsecured creditor in the CCAA process, a practice described as "cherry picking." 
The Court of Appeal appeared concerned, as well, about the effect that restricting termination and netting would have on risk management companies and, in particular, the steps such companies would take with their customers, such as requiring "cash strapped gas producers" to put up additional security to cover shortfalls. The Court of Appeal feared that such an effect would encourage business to migrate to the United States, where physically settled transactions were protected.

The Court of Appeal disagreed with LoVecchio J.'s distinction between financially settled and physically settled contracts. It held that, since eligible financial contracts include spot contracts as well as other contracts that could only be settled by physical delivery, such a distinction was inappropriate.

However, the Court of Appeal recognized that the broad definition of "commodity" could lead to a situation where virtually every contract to buy or sell on a future date would be a "forward commodity contract," since "commodity" could mean anything produced for use or sale. It agreed that such a broad interpretation would defeat the $C C A A$ 's predominant purpose, which was to preserve an insolvent company as a viable operation while reorganizing its affairs to the benefit both the company and its creditors. As a means of restricting the meaning of "commodity," the Court of Appeal decided to interpret that term to include only articles that are fungible in nature or, in other words, where each unit is interchangeable for another.

The Court of Appeal concluded that natural gas met the narrower definition of commodity, since one unit of gas is identical to another unit of gas and since natural gas trades on a highly liquid and volatile market wherein a price is readily ascertainable. It noted, however, that not every contract involving the purchase and sale of natural gas would be a forward commodity contract. For example, it held that the definition would not capture standard consumer gas utility contracts, which do not usually commit a consumer to purchase a specified volume of gas for a specified price.

Finally, the Court held that the decision would not lead to unfairness. It noted that while a manufacturer of consumer goods selling specified products to particular customers would encounter serious financial obstacles if, in CCAA proceedings, its customers were permitted to terminate contracts for the purchase of those goods, a gas producer would not suffer the same fate as a result of termination of long-term contracts. The gas producer, it held, could still sell its gas on the spot market or negotiate new long term gas supply contracts, perhaps on more favourable terms.

\section{J. Impact of the Eligible financial Contract Decision}

The Court of Appeal decision is an admirable attempt to balance the interest of insolvent companies under $C C A A$ protection and the volatile derivatives market. In coming to its decision, the Court of Appeal has expanded the ability of gas marketers to control their destinies when dealing with insolvent companies. It is clear that virtually every longterm contract for the sale of oil or gas will be considered an eligible financial contract. 
However, the Court of Appeal decision may have some unexpected results. For example, while the Court of Appeal obviously intended the definition of "forward commodity contract" would not include consumer contracts, the decision might not be so limited. For example, there are many businesses which enter into long-term contracts for the purchase of natural gas for their own use. Since these contracts would be for a specific amount to be delivered over a specific period of time, they would fall under the definition of "forward commodity contract" proffered by the Court of Appeal. Such a business could be greatly hindered in its attempt to use the CCAA process because its gas supplier could "turn off the taps."

It is also evident that the decision of the Court of Appeal may merely defer or alter the focus of future disputes in $C C A A$ proceedings regarding eligible financial contracts. While under the LoVecchio J. decision disputes would have arisen as to whether particular contracts were physically or financially settled, the Court of Appeal decision will result in disputes as to whether a particular contract deals with a "commodity." It is foreseeable that marketers of many different types of goods will attempt to describe their products as commodities.

Perhaps the solution to resolve any uncertainty in the eligible financial contract amendment in the $C C A A$ and the $B I A$ is to define the phrase "forward commodity contract." Another possibility would be to define a limited class of parties who would be able to rely on this exception to the stay power in s. 11 . This would bring the CCAA in line with American chapter 11 cases.

\section{The Operating facility Trust Decision}

On July 28, 1999, Justice LoVecchio issued a decision arising from an application by ANG Gathering and Processing Ltd. ("ANG") for a declaration that certain funds were held in trust for ANG by Blue Range as the "contract operator" of a gas processing facility. ${ }^{63}$

In September 1998 ANG purchased from Blue Range a 52 percent interest in a compressor station, a natural gas plant, an injection well, and the related gathering system of each. Blue Range retained a 48 percent ownership in these facilities. The ownership, operation, and use of the facilities was governed by an ownership and operation agreement ("OOA"), a contract operating agreement ("COA"), and a gathering and processing agreement ("GPA"). Blue Range and ANG were the only parties to the OOA and the COA. Blue Range and third party producers who used the facilities were parties with the "operator" to a GPA.

Under the OOA, ANG was named as the operator. Under the COA, Blue Range, as the "contract operator," assumed certain functions and responsibilities of ANG's operatorship. Blue Range also assumed certain of the functions and responsibilities of ANG under the GPAs to the producers. Most importantly, Blue Range was responsible for invoicing the producers. 
Blue Range's various roles can be summarized as follows:

Under the COA, it is the contract operator and responsible, as the representative of ANG, for collecting gathering and processing fees from all producers, including itself, and remitting payments to ANG, as Operator. Under the OOA it is also an owner, and entitled to a share of the distributions, after payment of operating expenses, capital costs, overhead and administration fees and other allowed expenditures. Under the GPA, it is a producer and responsible for paying gathering and processing fees to the Operator. ${ }^{64}$

The following provisions of the $\mathrm{COA}$ and $\mathrm{OOA}$ are relevant. The OOA, states:

\subsection{Sharing of the Facilities Account Among Owners}

(a) The Operator shall prepare for each Owner one or more statements for each month, comprised of:

The Owner's share of Facilities Revenue paid by all Producers to the Operator, net of Operating Costs and other applicable expenses, in proportion to that Owner's Facilities Ownership interest; and

(ii) The Gathering and Processing Fees payable by the Owner to the Operator determined in accordance with Owner's gathering and processing agreement with the Operator.

Each Owner shall pay to the Operator any balance of its Gathering and Processing Fees payable in excess of its share of Facilities Revenues for any given month. The Operator shall credit any net Facilities Revenues in an Owner's processing account to amounts owing for Operating Costs and Capital Costs in a month, and shall remit any net credit balance to the Owner.

(b) The Owners shall reimburse Operator for Capital Costs and that portion of Operating Costs that are not recovered from Producers, in proportion to their respective Facilities Ownership Interest.

(c) All payments to be made between the parties hereto shall be made within the applicable time periods specified in the Accounting Procedure. ${ }^{65}$

- [P]aragraphs 8.7 and $8.8 \ldots$ deal with the treatment of funds and the terms of payment between ANG and Blue Range. Those provisions read:

8.7 Funds advanced to the Operator by an Owner or received by the Operator for the account of an Owner shall be dealt with by the Operator in the manner provided for in this Agreement. All such funds are trust funds and shall not be used by the Operator for its own purposes. The Operator may commingle funds received by it under this Agreement with its own funds but such right to commingle is granted to the Operator as an administrative aid in its duties hereunder and shall not alter the characterization of such funds as trust funds. 
8.8(a) If an owner fails to pay when due its share of the costs and expenses as provided in this Agreement, the Operator may, without limiting the Operator's other rights at law, exercise any or all of the following remedies:

(i) set off against the unpaid amounts, monies due or accruing to the defaulting Owner from the Operator pursuant to this Agreement; and

(ii) by notice to any purchaser of the defaulting Owner's share of Gas or residue gas and plant products accompanied by a copy of this Agreement, direct that purchaser to pay to the Operator the proceeds of such production, which shall be applied toward payment of the amount unpaid, until such amount (together with all interest accrued thereon) is fully paid; and the Operator is hereby constituted irrevocably the attorney of the Owner for the purpose.... ${ }^{66}$

- [P]art of Schedule $\mathrm{C}$ to the OOA prescribes the accounting procedure. Paragraph 1.2(a) reads:

1.2(a) The Operator shall bill each Owner on or before the last day of each month for its proportionate share of the charges incurred on behalf of the Owner for the preceding month. Such bills will be accompanied by statements which identify all charges and credits, summarized by appropriate classifications of capital and expense; and ${ }^{67}$

- [P]aragraph 1.3 reads:

1.3 Each Owner shall pay all bills rendered under Clause 1.2 of this Accounting Procedure within 30 days of receipt thereof. Where the due date falls on a weekend or a statutory holiday, the payment will be due on the preceding business day. ${ }^{68}$

In the COA, article 3 reads as follows:

\section{RELATIONSHIP BETWEEN THE PARTIES}

\subsection{Operator as Named Operator}

The Parties hereby acknowledged that the Operator (defined as ANG) is the legal and recognized operator of the Facilities and nothing in this Agreement is intended to assign or transfer any of the Operator's rights or obligations as operator to the Contractor (defined as Blue Range). The Parties acknowledge that the purpose of this Agreement is to contract certain tasks and responsibilities to the Contractor involving the day-to-day field operations and general administration of the Facilities.

\subsection{Contractor as Independent Contractor}

The Parties hereby acknowledge that, subject to Clause 3.3, the Contractor is an independent contractor for the purposes of fulfilling all duties and responsibilities delegated by the Operator 
to the Contractor pursuant to this Agreement. Subject only to the further requirements and obligations of this Agreement, the Contractor shall have complete control and discretion with respect to the activities undertaken by it or any of its employees or subcontractors pursuant to this Agreement.

- Article 4 ... lists some of the Contractor's responsibilities. [The contractor shall:]

4.1(1) prepare all invoices and statements pursuant to the provisions of article 11;

4.1(m) diligently collect and remit payment of all Gathering and Processing Fees pursuant to the provisions of Article 11;

- Article 11 lists some of the Contractor's accounting and monetary responsibilities and reads in part:

\subsection{Statements as Operator}

(a) Within 60 days after the end of a given month, the Contractor shall prepare and deliver to the Operator a statement detailing the following for such month:

(i) Monthly Operating costs actually incurred, broken down by Facilities component and account categories (to the extent feasible) for the given month, with Contract Term-to-date cumulations;

(ii) Gathering and Processing Fees payable in respect of the given month;

(iii) The Administration and Overhead Fee payable in respect of a given month; and

(iv) The proposed remittance to the operator, which shall be equal to the net amount of (i).,(ii) and (iii) immediately above.

(b) The Contractor shall prepare and deliver to the Operator a monthly report detailing all accounts which are delinquent more than $\mathbf{3 0}$ days as at the date of each such report.

\subsection{Remittances to Operator}

(a) Within 60 days after the end of a given month, the Contractor shall remit to the Operator:

(i) that net remittance as identified in subclause 11.3(a)(iv); minus

(ii) any unpaid Producer invoices included in subclause 11.4(a)(i); plus

(iii) any other amounts, if any due to the Operator from Producers pursuant to the Gathering and Processing Agreements and paid to the Contractor since the previous remittance; plus

(iv) a statement reconciling the foregoing remittance against the immediately preceding statement delivered to the Operator.

\subsection{Trust Funds}

With the exception only of those funds which the Contractor is entitled to retain for its own benefit hereunder, all funds received by the Contractor from the Producers or others for the account of the Operator shall be dealt with by the Contractor in the manner provided for in this Agreement. All such funds are hereby designated as trust funds and are not to be used by the Contractor for its own purposes. The Contactor may 
commingle funds received by it pursuant to this Agreement with its own funds but such right to commingle is granted to the Contractor as an administrative aid in fulfillment of its duties hereunder and does not alter the characterization of such funds paid to or received by the Contractor as trust funds."i)

Blue Range invoiced all third party producers for their share of gathering and processing fees and created an internal statement for its own share of those fees. Upon receipt of the internal statement, Blue Range acknowledged receipt by it of the statement and recognized its obligation as a producer to pay such fees. This was followed by a net payment to ANG of its share of the gathering and processing fees earned by the facilities, less the appropriate deduction by Blue Range for administration and overhead fees. There was no actual payment by Blue Range to itself of the fees and no corresponding receipt by Blue Range as the contract operator. In short, Blue Range forwarded only a net portion of the gathering and processing fees to ANG. Due to this accounting scheme, ANG and Blue Range disputed whether Blue Range held trust funds. Under subclause 11.6 of the COA, the funds must have been "received" by Blue Range to constitute trust funds. ANG claimed that the journal entry described above constituted a receipt, thus invoking the trust.

Justice LoVecchio held that the funds received for gathering and processing fees by Blue Range from producers other than Blue Range were held in trust for the benefit of the operator on behalf of the owners under subclause 11.6 of the COA. Blue Range conceded this point with regard to producers other than Blue Range. LoVecchio further held that the gathering and processing fees that Blue Range as contract operator recorded and credited to itself as one of the producers were not trust funds received by Blue Range and, therefore, were not impressed with the same trust as funds received from third party producers.

In identifying the issue as the meaning of "received" as set out in the COA, Justice LoVecchio stated that:

\footnotetext{
Either, (i) Blue Range as a "Producer" was not required to pay Blue Range, as the "Contract Operator" for its share of the "Gathering and Processing Fees" so long as ANG received at the end of the day the net amount it would ultimately be entitled to receive, as an "Owner," from Blue Range the "Owner/producer" under the COA, or (ii) Blue Range, as the "Contract Operator," was required to collect payment from all of the "Producers," including itself, and has received actual payment from the "Producers," other than itself and has constructively received payment from itself upon making the journal entry. This actual receipt combined with the constructive receipt makes all of these amounts subject to a trust for $\mathrm{ANG} .^{70}$
}

He then held that the former interpretation was correct. He stated that it was clearly the intention of the parties that the gathering and processing fees received from producers were to be impressed with a trust. The parties were aware that Blue Range as an owner would also be one of the producers. 
Justice LoVecchio stated that were it not for the OOA, he would agree with ANG that Blue Range ought not to be able to avoid the trust protection provided to ANG by using particular internal accounting procedures. However, the OOA, in clause 8.3, as set out above, contemplated Blue Range would pay ANG "any balance of its gathering and processing fees in excess of its share of facilities revenue for any given month."

He concluded as follows:

To accept ANG's argument, I must find that the parties intended at the time they entered the COA that it, in subclause 11.6 in particular, would govern the mode which governed the payment of fees payable by Blue Range and that they would cease to be governed by the $O O A$.

Is that the case? Under the OOA, if Blue Range, as an "Owner" defaulted on its payment obligations, ANG would be an unsecured creditor for (i) its share as an "Owner" of the fees attributable to the use of the facilities by Blue Range, and (ii) Blue Range's share of the "Operating Costs and Capital Costs" properly chargeable by ANG. Under the OOA, ANG would be partially protected from the financial impact of this default. By its control of the fees received from "Producers," other than Blue Range, it could utilize Blue Range's $48 \%$ portion of those fees, as an "Owner," as a setoff against the two items listed above as it was only obligated to remit any "net credit balance" in the Owners' processing account to Blue Range.

To find that a trust exists through a constructive trust has the effect of upgrading the position of ANG. ANG under the trust arrangement would have access to the entire fee obligation of Blue Range not the net position.

The COA was a delegation to Blue Range of part of the role of ANG under the OOA. To hold that a delegation involved an upgrade of their position would to me require a reference in the COA which effectively suspended or amended the operation of subclause 8.3 of the OOA. ${ }^{71}$

Justice LoVecchio's decision is important because it reflects the court's role in determining the validity of trust arrangements. Typically, in insolvency matters, parties will seek ways of maximizing their share of the insolvent company's estate or their dividend in a restructuring period. Often this takes the form of a claim of a trust or a secured position. LoVecchio J.'s decision exemplifies the type of analysis required in working through the interlocking contracts typically associated with facility operations.

\section{The "LATe Claims" Decision}

Although not of particular interest to the petroleum industry, the November 9, 1999, decision of Justice LoVecchio with regard to late claims is of interest to insolvency practitioners. $^{\text {22 }}$

As is typical in $C C A A$ proceedings, a claims procedure was established by the court. Under the procedure materials were distributed to creditors at the addresses on the records 
of Blue Range by facsimile, courier, or single registered mail. A notice was also required to be published in a number of newspapers. A claims bar date was set at May 7, 1999, and was later extended to June 15,1999 . The order establishing the claims file procedure stated that those claims not proven by the claims bar date would be "deemed to be forever barred." Pursuant to the claims procedure, some $\$ 270$ million in claims were filed. Some claims were allowed in full, some were denied in full, some were allowed in part, and in some cases, there were disputes as to whether the claims were secured or unsecured. The claims procedure also established an appeal process.

Certain creditors filed their notices of claim after the applicable claims bar date and sought permission to file their late claims. Other creditors sought to amend their claims after the claims bar date. Finally, one creditor sought to appeal a decision of the monitor in the claims procedure after the expiry of the appeal period.

Justice LoVecchio was faced with three issues:

(1) Should the court, under all the circumstances, refuse to extend the claims bar date or a period during which an appeal may be made when it was the court that had established the particular milestones in the course of its supervisory role?

(2) If the answer to issue number 1 was no, in what circumstances should the court extend time?

(3) If the answer to issue number 1 was no and the court established circumstances for the extension, did the applicants in the particular case establish those circumstances?

Justice LoVecchio determined that the court should not, under all circumstances, refuse to extend time under the claims process. He noted that the claims procedure was very detailed and intended to affect substantive rights. He also noted that the claims bar procedure was in essence, an ex parte order, as, with few exceptions, those affected by the order were not served with the notice of the application due to the great numbers of creditors.

While Justice LoVecchio acknowledged that a refusal to extend time under any circumstances would provide certainty of process, such a result would risk undermining respect for the process as it would be seen as harsh and arbitrary. The impact of that approach would mean that the court could not remedy an injustice and would prevent a creditor from pursuing a claim that, absent the $C C A A$, would have survived for several years under normal limitation rules even where the creditor had justifiably missed the claims bar date.

Justice LoVecchio also recognized that creditors relied upon the claims procedure and the claims bar dates established thereunder. Creditors rely on their knowledge of the claims that have been proven under the claims process in assessing their recovery under a proposed plan of arrangement and voting according to that review. However, Justice LoVecchio determined that such reliance was not a sufficient reason for the court to affect substantive rights without at least some flexibility in the process. The effect of that approach would result in the court assisting those who filed their claims in accordance 
with the order to defeat others whose claims were equally valid but for the orders of the court extinguishing them. It would deny any recovery to creditors who had a logical explanation for their non-compliance. The compromise of those creditors under the plan of arrangement would become 100 percent of the amount owed to them.

With regard to the second issue, Justice LoVecchio determined that the circumstances under which a creditor could be afforded an extension of time would depend upon the type of plan of arrangement being proposed. Where a "liquidation plan" was before the creditors Justice LoVecchio decided that an approach similar to that under the BIA should be utilized. This approach is fairly liberal in permitting extensions of time for filing proofs of claim due to the expectation held by the creditors that they will share the impact of the liquidation.

On the other hand, if the proposed restructuring was a sale of the business to, or the infusion of cash by, a third party who would absorb the loss by itself, a more restrictive approach might be appropriate. Since the Blue Range plan of arrangement involved the sale of Blue Range's assets, the more liberal $B I A$ approach was proper. Under that approach, lateness due to inadvertence or to incomplete information was an acceptable excuse for a late filing and an extension of time was granted. The ability of a creditor to take part in the proceedings depended upon the steps that had already occurred prior to the "late" filing. For example, if a vote had taken place or a partial distribution had occurred, the late filing creditor would not participate in those steps. Justice LoVecchio concluded that, "in essence, the $B I A$ approach would permit almost any circumstance provided a distribution had not been made," and "even if one had been made, the change would likely be permitted, but without retroactive effect." to be applied in the Blue Range situation, all of the applicants were permitted to file late claims.

The Court of Appeal recently upheld LoVecchio J.'s decision. The late claims decision is of great importance to insolvency practitioners as it establishes the guidelines for assessing whether or not late claims will be permitted.

\section{Builders' Liens - Prevenient ARRangements}

As discussed above, one common occurrence in an insolvency case is an attempt by creditors to maximize their recovery by asserting a trust or secured claims. For many trade creditors this involves the assertion of a builders' lien. Because the time for filing a builders' lien under the relevant lien legislation is short, ${ }^{74}$ such creditors often find themselves with a large account receivable for work done outside the lien period and a small account done within the lien period. Often such creditors attempt to file liens for the entire amount owed, arguing that the work was done under a "prevenient arrangement," thereby enabling all of the work to be tacked together such that the date of the last work done is the relevant date for lien purposes.

74 See, e.g.. Builders' Liens Act, R.S.A. 1980, c. B-12, s. 30 (providing for a forty-five day window). 
This was the case in Blue Range. The monitor disallowed all of the liens for which a prevenient arrangement was claimed and classified such claims as unsecured. The lien claimants challenged that decision and, on November 16, 1999, Justice Romaine issued a decision. ${ }^{75}$

Justice Romaine set out the following characteristics of a prevenient arrangement:

(1) There must be a "preliminary understanding between parties that they are entering into an ongoing relationship."

(2) "This preliminary understanding does not have to be a binding contract or contain all the terms upon which materials or services are being supplied, but it serves to link together what would otherwise be a series of contracts into one continuing contract or open account."

(3) "A longstanding commercial relationship between a supplier or serviceman and a customer does not in itself create a prevenient arrangement": the court must find an intention to create a continuing contract.

(4) Where the result of finding a prevenient arrangement "is to give the lien-claimant priority over other creditors, care must be taken to ensure that the evidence adducing establishes ... the 'necessary thread' to establish a prevenient arrangement."

(5) "The onus is on the lien claimant to establish the prevenient arrangement."

(6) "It is not necessary that the preliminary understanding involve a specific project, but the scope and extent of the work to be done ... must be determinable with a sufficient degree of certainty."

(7) "Although a specific project is not necessary, the strength of such a factor" in providing a degree of certainty is important.

Justice Romaine held that none of the three lien claimants before her had established a prevenient arrangement.

The first lien claimant, National-Oilwell Canada Ltd. ("National-Oilwell") claimed a lien in respect of the supply of parts and equipment for oilfield equipment. NationalOilwell had entered into an agreement with Blue Range with regard to pricing for the equipment and the term of payment. This agreement was not reduced to writing and was not an exclusive arrangement. There was no evidence that there had been a discussion of a specific project with regard to the arrangement. Justice Romaine held that an arrangement, whereby a purchaser makes purchases over time on certain terms, was not enough to establish a prevenient arrangement. 
Drivewell Servicing ("Drivewell") claimed a builders' lien for the supply of service rigs and crews to Blue Range. It provided written quotes to Blue Range setting out rates for various services. It was not an exclusive supplier of such services, but was the preferred supplier. Justice Romaine held that Drivewell's situation had more of the hallmarks of a prevenient arrangement than the other two claims:

It was an understanding between the parties for work to be provided at a certain price for a distinct period of time. Although detailed specifics of the work were not discussed, there was a general understanding of some of the requirements and a framework was set up for further contact between the parties. The understanding was reduced to writing in the Contract Summaries. ${ }^{76}$

However, the foregoing was insufficient to establish a prevenient arrangement. Justice Romaine noted that there was no determinable minimum or maximum services to be requested or provided and no designation of specific services. The wells were not linked in any other way than by the fact that Blue Range owned or operated all of the wells. The wells were individual projects, and each was financially significant.

Finally, Justice Romaine considered a lien claimed by Smoky Oilfield Rentals Ltd. ("Smoky") in respect of the rental of equipment. The unwritten agreement between the parties was that Smoky would provide equipment as requested at Smoky's going rates. While Smoky had a close and effective working relationship with Blue Range, the relationship was not exclusive. The earlier contact between the parties may have facilitated later rentals, but it was insufficient to establish any kind of link between the separate rental transactions. Accordingly, no prevenient arrangement existed.

Romaine J.'s decision establishes that it will be very difficult to link services or supply of materials by a particular trade creditor over time in such a way that a prevenient arrangement is established and a valid lien asserted in respect of an entire account owed by an insolvent company. The decision reflects the concern that such trade creditors not be given an undue advantage over other trade creditors, given the limited resources for repayment of debts owed by the insolvent company. Most importantly, the decision establishes what will not qualify as a prevenient arrangement. However, it does not provide an example of what will qualify as a prevenient arrangement.

\section{The Subordinated Damages Decision}

On January 10, 2000, Justice Romaine issued a decision with regard to a claim by Big Bear for damages arising from its takeover of Blue Range. " Big Bear alleged that Blue Range had made misrepresentations that caused Big Bear to complete the takeover of Blue Range. That takeover involved a share transfer. Big Bear claimed as damages the value of its shares issued in order to take over Blue Range.

Justice Romaine held that, assuming the claim of Big Bear to be valid, it was subordinated to other unsecured creditors with regard to voting rights and distribution of

$7 \quad$ Blue Range Resource Corp. (2000), 259 A.R. 30 (Q.B.). 
the proceeds of the sale of Blue Range's assets. While the Big Bear claim was, like the others, an unsecured claim, Justice Romaine held that it was a claim arising from Big Bear's status as shareholder and that, therefore, Big Bear ought not to occupy the same priority position with regard to the proceeds. Justice Romaine noted that the damages sought by Big Bear were akin to a claim of rescission, which is not permitted against an insolvent company.

This decision is important because it implicitly recognizes the notion of a subordinated class of unsecured creditor. Previously, the concept of equitable subordination had not been confirmed in $C C A A$ proceedings.

\section{Conclusion}

The Blue Range $C C A A$ proceedings have been regarded in the industry as fairly successful. Unsecured creditors received a greater dividend than in most $C C A A$ proceedings and, of course, the secured creditors of Blue Range were paid in full. From a legal prospective, the Blue Range insolvency has provided in some instances greater certainty with respect to insolvency law in the oil and gas industry, particularly with regard to the termination of contracts and eligible financial contracts. In other legal issues, the decisions arising from the Blue Range insolvency may raise more questions than they answered. For example, the set-off decision, dedication of reserves and the subordinated damages decision have the potential to cause uncertainty. In any event, the Blue Range insolvency has been the source of interest among insolvency practitioners and the oil and gas industry. 